\title{
Person names in constriction field (on basis of English, French, Tatar and Russian languages)
}

\author{
Gulnara Lutfullina*1[0000-0003-1572-5314], and Elvira Ibragimova ${ }^{1}$ \\ ${ }^{1}$ Kazan State Power Engineering University, 420066 Kazan, Russia
}

\begin{abstract}
In this article construction profession names were investigated using the corpus-linguistic method. We have identified quantitative differences in the functioning of lexemes. The frequency of the functioning of professional names is determined by their structural features. An effective principle for creating professional names is to choose a one-component term that etymologically ascends to international vocabulary. The results of the study revealed significant differences between professions names and also confirmed the relevance of corpus linguistic methods.
\end{abstract}

Keywords. Construction profession names; corpus linguistics; intercultural research.

\section{Introduction}

The interpretation of person names meaning by linguists is greatly influenced by works in the field of philosophy. Important differences in person names functions have been established in the works on vocatives and nomination. Most grammarians think that proper nouns are a subtype of nouns, while some argue that they hold a special position. However, this is based on the fact that each occurrence of the person's name form is categorically a name and not a derived noun.

Person names belong to a functional category shared with other determinants which also creates difficulties. There has been much works on the classification of names and the derivational relationship between names and other categories.

Classes of words differ in combinations of conceptual features, differences in syntax and in distribution between individual classes. A distinction is made between lexical (noun, verb, adjective) and functional categories. The sentence structure is projected from the valence and modification requirements of the members of these categories.

Person profession names represent a separate level of nomination of persons called classifiers. First level nomination presupposes the generic attribute «human being» with the specification of gender. At second level nomination the classifiers determine the belonging of a person to a certain class. In case of professional names, we mean a class of jobs. Third level nomination of persons is represented by anthroponyms or identifiers.

In this article we consider a separate group of professional classifiers - professions names of construction. The purpose of the article is to determine the frequency the names of

${ }^{*}$ Corresponding author: gflutfullina@mail.ru 
construction professions in four languages. Research objectives: 1) compile a list of analyzed professions based on equivalents; 2) collect quantitative data on frequency; 3) analyze the structure of person names and determine the dependence of the frequency indicators; 4) consider syntactic functions. The relevance of the study lies in the fact that the frequency of functioning of professional names of a person is determined by their structural features. It is necessary to identify effective principles for creating professional names.

\section{Materials and methods}

General scientific methods of generalization and analysis, method of comparative analysis, methods of computer linguistics, methods of distribution, component, quantitative method are used in this article. The material of the study was the data from 3 linguistic corpuses: British National Corpus, Tatar National Corpus, Russian National Corpus and data from yahoo.fr. site. In our article we identified quantitative differences in functioning of profession names relying on corpus linguistic methods [1].

\section{Results}

The translation of construction professions names presents difficulties. The choice of appropriate equivalents is not always obvious: English term may not always match to other language term. Compared term mason is often regarded as an equivalent in bilingual dictionaries. However, its denotations can differ significantly, so their translation can lead to intercultural misunderstandings.

Translators find it difficult to identify equivalents for construction professions names due to intercultural differences in designations and titles. For example, in English, mason is used more broadly. In Russian a mason designated member of a public organization. Professions names cannot be considered full equivalents of their translations, since the words differ both linguistically (syntactically and semantically) and culturally.

Construction professions appear in specific contexts and can be most effectively explored in specific linguistic and cultural contexts. Construction profession names can have different connotations and denotations and significantly differing cultural meanings.

The aim of the study is to analyze the cross-cultural dimension of construction professions names, which can influence the communication process inside and outside the construction industry. This study compares construction job titles in a cross-cultural context. We have found 14 construction job titles.

In Russian: инженер-строитель, архитектор, геодезист, экономист, технолог, мастер строительных и монтажных работ, крановщикк, рабочий при создании железобетонных сооружений, столяр-плотник, кровельщик, бетонщик, монтажник по монтажу стальных и железобетонных конструкций, каменщик, облищовщик для внутренних и наружных работ, маляр-штукатур.

In Tatar: инженер-төзүче, архитектор, геодезист, икътисадчь, технолог, төзелеш һәм монтаж эиләре мастеры, крановщик, тимер-бетон корылмалар төзегәндә эщче, балта остасы, түбә ябучы, бетончы, корыч һәм тимер-бетон конструкииллрне монтажлау буенча монтажчы, ташчы, эчке һәм тышкы эшләр өчен тышлаучы, маляр-итукатур.

In English: civil engineer, architect, surveyor, economist technologist, master of construction and installation works, crane operator, worker in the creation of reinforced concrete structures, carpenter, roofer, concrete worker, installer for the installation of steel and reinforced concrete structures, bricklayer, mason, revetter for interior and exterior work, painter-plasterer. 
In French: ingénieur civil, architect, arpenteur, économiste, technologue, maître des travaux de construction et d'installation, grutier, travailleur lors de la création de structures en béton armé, charpentier, couvreur, bétonneur, monteur pour l'installation de structures en acier et en béton armé, maçon, parement pour les travaux intérieurs et extérieurs, peintreplâtrier.

We decided to analyze three structurally different names: architect, civil engineer, master of construction and installation works.

The choice is due to the fact that these professional names represent a simple term, a twocomponent term and a multicomponent term.

Their frequencies are presented by linguistic corpus of the corresponding languages: British National Corpus, Written corpus of Tatar language, National corpus of Russian language. French language data is taken from the site yahoo. fr. Some missing quantitative data are also obtained from site yahoo. eng.

Due to the unevenness of the selection of corpora and sites, the proportional relationship of frequency of terms use is considered based on obtained quantitative data.

According to the corpus data and to sites data we obtained the following information:

\section{In Russian:}

архитектор (13 800 000/2301 tokens)

инженер-строитель (8 400 000/1155 tokens)

мастер строительных и монтажных работ (7830 000 tokens)

In English:

architect (1533 tokens)

civil engineer (91 tokens)

master of construction and installation works (1 collocation)

In French:

architecte-architect (60 100000 tokens)

civil engineer (1 380000 tokens)

maître des travaux de construction et d'installation (8900 000 tokens)

In Tatar:

архитектор (3387/187 tokens)

инженер-төзүче (9 tokens)

төзелеш һәм монтаж эшләре мастеры (1 collocation).

This allows us to calculate the ratio of terms:

In Russian: архитектор - инженер-строитель - мастер строительных и монтажных работ = 14: 8,5: 8;

In English: architecte-ingénieur civil-maître des travaux de construction et d'installation $=15: 1: 0$;

In French: architecte- architect- civil engineer-maître des travaux de construction et d'installation $=60: 1.5: 9$;

In Tatar: архитектор - инженер - төзуче - төзелеш һәм монтаж эщләре мacmepbl $=20: 1: 0$.

As you can see from the above results the monosyllabic name of construction profession is quantitatively dominant in all languages. We thought that this is due to the widespread use of this name not only in the construction industry. In all languages except Russian one share of total number of one-component name frequency an architect is equal to frequency of highly specialized name a civil engineer. The multicomponent term is practically not represented in terms of the frequency, although we have considered its more simplified variants more common in European languages, - manager of construction.

We decided to reveal the frequency of a generic profession name in construction industry - person name - a builder. Frequency indicators were distributed as follows: in Russian: строитель $=1155$; in English: builder $=918$; in French batisseur $=3470$; in Tatar: 
tezYche $=10405$. It should be noted that the lesser frequency of the generic name in English and French is due to the fact that it functions only in the specific meaning of a builder of buildings. The frequency of the word a constructor also is not high (33 tokens in BNC). This name is already transformed into the designation of another profession - a constructor in the more general sense of «constructor»: an aircraft constructor, a a constructor at a factory. In Tatar the high frequency is due to the fact that the given name of the person realizes the abstract meaning of «a builder»: the builder of socialism, the builder of family relations.

Let's consider examples of functioning and realizing of syntactic functions:

(1) ... a student, civil engineer, architect and pensioner - were taught the basics of railway safety and signaling ... [BNC] [2].

(2) ... marked an upsurge in the family fortunes in every way. Gus, a civil engineer, had been finding the job situation pretty difficult and during the period... [BNC] [2].

(3) Paddy Barry, a 47-year-old a civil engineer from Dublin, is the latest winner of the Blue Water Medal of the Cruising ... [BNC] [2].

(4) Name there used to be an architect and name has a degree in law '[BNC] [2].

(5) Secondly, he was accepted as the single-handed architect and creator of Germany's 'economic miracle' of the $1930 \mathrm{~s}$... [BNC] [2].

(6) ... this year's building manager of the Year Awards and the adjudicating panel is well on its way to a... [BNC] [2].

(7) Significant sponsorship has been attracted to the building manager of the Year Awards, and the profile of this event has risen considerably [BNC] [2].

(8) Continue to develop the profile and financial independence of the building manager of the Year [BNC] [2].

In English, these profession names function in sentences (1)-(8). In these examples the persons names perform their typical syntactic functions: subject (1), (6), clarifying object (2), (3), part of the nominal predicate (4), object (7), (8).

(9) Dans son acception classique, l'architecte est d'abord un artiste et accessoirement un technicien (spécialisé dans l'art de la conception des bâtiments [yahoo.fr] [3].

(10) Autan de projets qui ne voit le jour sans l'intervation d'un architecte. Ce maître d'oeuvre exerce le plus souvant en liberal...[yahoo.fr] [3].

(11) Un ingénieur civil est un ingénieur dont la particularité correspond à des statuts différents selon l'époque et le pays [yahoo.fr] [3].

(12) Description du poste de maître d'oeuvre des travaux de construction et d'installation. Description de travail typiques ... [yahoo.fr] [3].

In French these profession names function in sentences (9)-(12). In the above proposals the following functions are implemented: subject (9), (11), object (10).

(13) Ул рәссам_гына түгел, архитектор, скульптор_да... (А. Вергазов) [TNC] [4].

(14) Сез менә инженер-төзүче, хәләл ризыгыгызны төрле проектлар, исәпхисаплар төзеп, ягъни башыгызны эшләтеп табасыз (А. Хәсәнов) [TNC] [4].

(15) ...әсәрдә төзелеш мастеры Гәрәй Шаминның чын тормыш борчулары, эш мәшәкатьләре, шатлыклары, үзе инанган максатка бару юлындагы киртәләрне жимерү, вакытлы жиңелүләрнең ачысы - барысы да вакыйгалар тезмәсе рәвешендә генә түгел, ә күңел хәрәкәте аша жанландырып сурәтләнә (Истәлекләр) [TNC] [4].

In Tatar the syntactic roles of nominal part of predicate (13), (14) and objects (15) are found.

(16) Архитектор Инна Барановская настроена более оптимистично. Она пишет: «Приведённая вами статистика - уже показатель общественного мнения/Architect Inna Baranovskaya is more optimistic. She writes: "The statistics you cited are already an indicator of public opinion» (T. Savelyeva) [RNC] [5].

(17) Я инженер-атомщик, строитель Обнинской атомной станции/I am an atomic engineer, builder of the Obninsk nuclear power plant [RNC] [5]. 
(18) Мастер строительных и монтажных работ- должность, относящаяся к категории инженерно-технических работников, и имеющая статус .../Master of construction and installation works - a position belonging to the category of engineering and technical workers, and having the status of ... [RNC] [5].

In Russian the predicate function (17), (18) and object function (16) dominate.

\section{Discussion}

Many works are devoted to the study of the functioning of the names of person [6], their definiteness / indefiniteness [7], their relations with other parts of speech [8,9], their syntactical functions [10-12]. Special attention is given to proper names [13-15]. Studies of professional names occupy a small place. The names of professions are often considered within the analysis of the terminological apparatus of a particular field of activity. Among the recent works, one can note the fundamental work of J. Andersen «The Grammar of Names» [16], devoted to the study of both separate anthroponyms and the general theory of all names of a person. An interesting study is devoted to the relationship between anthroponyms and professional names. The analysis of professional names and their associative connection with a number of anthroponyms is considered in the work of A. Kaufman [17]. The methods of corpus linguistics and associative experiment are used in the analysis of the functioning of professional names in the medical field by Lenart Istvan and N. Buvalin [18]. The interdependency of profession name structure and their frequency is never studied before. The importance of person name study is recognized within the frame of semantics and pragmatics investigations $[19,20]$.

\section{Conclusion}

Thus, we have included 14 terms in the list of the most frequent names of construction professions. analyzed professions based on the search for equivalents. According to the obtained quantitative data, the monosyllabic name of the construction profession names dominates in all languages. The frequency of multicomponent term is practically not presented. The generic name a builder is less common in English and French. In Tatar the high frequency is due to functioning in an abstract sense. Examples of person names functioning made it possible to record similar syntactic functions in all languages.

\section{References}

1. Mark Davies. Corpus of News on the Web (NOW): 3+ billion words from 20 countries, updated every day (2013). URL: https: //www.corpus.byu.edu/now (date of access: 01.12.2020).

2. [BNC] British National Corpus. URL: https:/www.english-corpora.org/bnc/ (date of treatment: 01.12.2020).

3. [yahoo.fr]. URL: https:/www.english-corpora.org/bnc/ (date of access: 01.12.2020).

4. [TNC] Written corpus of Tatar language or Tatar National Corpus. URL: https://www.corpus.tatar/ (date accessed: 01.26.2020).

5. [RNC] National corpus of the Russian language or Russian National Corpus. URL: $\mathrm{http}: / / w w w . r u s c o r p o r a . r u /$ (date of treatment: 01.12.2020).

6. Blount Ben. Personal names. (2015). URL: https://www.researchgate.net/publication/ 303519288_Personal_Names (date accessed: 01.26.2020). DOI:10.1093/oxfordhb/ 9780199641604.013.011.

7. B. Abbott. Definiteness and Indefiniteness. In L.R. Horn \& G. Ward (eds.) (2004). 
DOI: $10.1002 / 9780470756959 . c h 6$.

8. A. Asudeh. Relational nouns, pronouns, and resumptions, Linguistics and Philosophy 28 (4), 375-446 (2005). DOI: 10.1007/s10988-005-2656-7.

9. S. Löbner. Types of nouns, NPs, and determination. Ms, University of Düsseldorf (2010).DOI: $10.1093 /$ jos/ffq022.

10. D. Graff Fara. Names are Predicates, Philosophical Review 124 (1), 59-127 (2015). DOI 10.1215/00318108-2812660.

11. A. Gray. Lexical Individuation and Predicativism About Names, Thought 4 (2), 113-123 (2015). DOI: $10.1002 /$ tht3.164.

12. R. Jeshion. Names Not Predicates, in A. Bianchi (ed.). On Reference. Oxford : Oxford University Press (2015). DOI: 10.1093/acprof:oso/9780198714088.001.0001.

13. Common English Surnames Derived from Occupations (2020). URL: https: /www.english-corpora.org/bnc/ (date of treatment: 01.12.2020).

14. Joao Pina-Cabral. Names of Persons (2015).

15. D. Rami. The Use-Conditional Conception of Proper Names, Philosophical Studies 168 (1), 119-150 (2014).DOI: 10.1007/s11098-013-0264-x.

16. John M. Anderson. The Grammar of Names. Studies on the linguistics of names, Oxford Scholarship Online, 234 (2007). DOI:10.1093/acprof:oso/9780199297412.001.0001.

17. Alexander C. Kaufman. What Your Name Says About Your Job (2017). URL: https: //www.corpus.byu.edu/now (date of access: 01.12.2020).

18. Istvan Lenart, N. Buvalin. Cultural Aspects of Malaysian English and Russian Medical Profession Names, The Southeast Asian Journal of English Language Studies 26 (2), 24-36 (2020).DOI: 10.17576/3L-2020-2602-02.

19. A. Stokke. Intention-Sensitive Semantics, Synthese 175 (3), 383-404 (2010). DOI: 10.1007/s1 1229-009-9537-5.

20. The Handbook of Pragmatics, Oxford: Blackwell, 122-149. ISBN: 978-0-470-75671-3. 